\title{
Performance of lime-treated silty soil under long-term hydraulic conditions
}

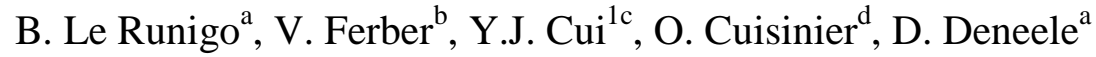

${ }^{a}$ Laboratoire Central des Ponts et Chaussées de Nantes, Division RMS, Route de Bouaye, BP4129, 44341 Bouguenais cedex, France

${ }^{\mathrm{b}}$ Entreprise Charier, Service R\&D, 87-89 rue Louis Pasteur, 45550 Montoir-de-Bretagne,

France

${ }^{\mathrm{c}}$ Ecole des Ponts ParisTech, UR Navier - CERMES, 6 et 8 avenue Blaise Pascal, Cité Descartes, Champs-sur-Marne, 77455 Marne-la-Vallée cedex 2, France

(E-mail: cui@cermes.enpc.fr, Tel: +33 1 64153550, Fax: +33 1 64153562)

${ }^{\text {d }}$ Nancy-Université, LAEGO, Vandoeuvre-lès-Nancy, 54501 France

${ }^{1}$ Corresponding author 


\begin{abstract}
The durability of the mechanical improvements brought by lime once the involved earth structures are exposed to long-term hydraulic conditions (long-term water contact and water circulation) is still under discussion. This paper aims at assessing i) the impact of such hydraulic conditions on the mechanical shear strength of a lime-treated silty soil, and ii) the effect of initial conditions (lime content and compaction conditions) on the lime treatment durability. The results showed that water contact leads to a significant decrease in shear strength. The results also indicated that the mechanical performance of soils exposed to water circulation is highly related to the quantity of water passing through the soil specimens and hence to the permeability of the soils: the lower the permeability, the better the durability. Futhermore, it has been observed that a lime content higher than the lime modification optimum (LMO) enables a better homogeneity of the treatment, giving rise to a longer resistance to water circulation.
\end{abstract}

Key-words: Jossigny silt, lime treatment, durability, water circulation, mechanical strength, permeability. 


\section{Introduction}

In the context of sustainable development, there is an increasing need of retrieving and reemploying the materials encountered in the vicinity of the earthwork projects, whatever their nature or water content. In this regard, lime stabilization is one of the methods widely used nowadays to overcome the problems related to the poor mechanical characteristics of certain soils. It leads, through the development of physico-chemical processes to an improvement of the soil workability and mechanical properties. Cation exchange, combined with the presence of large amounts of calcium ions on the adsorbed clay particles surface (due to the lime added), leads to a reduction of the diffuse double layer size. This process gives rise to clay particles flocculation. It is generally accepted that the cation exchange and the flocculation occur shortly after the addition of lime and lead to a decrease of the soil plasticity (Eades and Grim 1966; Rogers and Glendinning 1996). Besides, the addition of lime also results in a high $\mathrm{pH}$ environment which enables the dissolution of silica and/or alumina present in the soil from which cementitious compounds such as hydrated calcium silicates or hydrated calcium aluminates (C-S-H and C-A-H) can be formed. As a result, an improvement in the soil mechanical properties can be expected, the extent of the improvement being dependent on the amount of lime added, the effectiveness of compaction, the curing time and the nature of the soil treated (Fossberg 1965; Wissa et al., 1965; Brandl 1981; Balasubramaniam and Buensuceso 1989; Bell 1996, Little 1995; Balasubramaniam et al. 2005). The obtained results suggest that lime-treatment increases the preconsolidation pressure of soils. Furthermore, the lime addition increases the shear strength by both the flocculation process and the formation of cementitious compounds. It has been found that the shear strength increase depends on the soil properties (clay fraction, clay type, Atterberg limits, etc.).

Although lime treatment has been widely used in embankment constructions, its use for the construction of hydraulic structures (dikes, river levees, dams, etc.) or of embankments in flooding areas remains, at least in France, controversial. In fact, the durability (i.e. the capacity of structures to maintain long-term performance defined in the design) of the mechanical improvements brought by lime once earth structures are exposed to long-term water contact or water circulations is still unclear. This is probably due to the low number of studies carried out on this subject. De Bel et al. (2005) conducted a study on a lime-treated silty soil subjected to different leaching times. Their results indicate that long-term water circulation is detrimental to the durability of hydraulic earth structures since the unconfined compressive strength of the lime-treated soil decreased significantly with the leaching time. Different assumptions were proposed by the authors to explain this decrease: i) saturation of the soil and thus increase in the soil moisture content or decrease of soil suction, ii) calcium leaching due to the decalcification of the cementitious compounds. The strength loss as well as the calcium leaching seemed to be less pronounced when the curing time was long. This may be due to a better crystallization of the cementitious compounds with long curing time. Other authors (McCallister 1990; McCallister and Petry 1992) who studied the leaching effect on lime-treated plastic clays compacted at different moisture contents also showed that leaching leads to a decrease in the soil strength by $15.1 \%$ to $86.0 \%$, depending on the soil nature and lime contents. They also showed that the strength decrease could be minimized, even neutralised, by adding large amounts of lime (from $4 \%$ to $8 \%$, depending on the soil considered).

Another unanswered question involves the impact of the soil initial state on the short and long-term mechanical performances, especially under long-term leaching conditions. In other words, from a practical point of view, it would be very helpful to know whether controlling compaction moisture content and dry density can contribute to improve the longterm mechanical properties. Several studies were conducted on the impact of compaction moisture content on the soil mechanical properties; but the effect of the compaction energy 
has been scarcely studied. Estéoule and Perret (1979) indicated that compaction moisture content plays an important role in the evolution of the unconfined compression strength of a lime-treated silty soil. Petry and Berger (2006) studied three different clayey soils and showed that the highest unconfined strength is reached when compacting the soils close to their optimum moisture content. This may be due to the highest dry density reached in that case. Wissa et al. (1965) showed that an increase in the dry density of lime-treated soils could lead to an increase of the effective cohesion, the internal friction angle remaining stable. Finally, the study conducted by McCallister (1990) showed that soils compacted dry of optimum exhibit the highest permeability and the most significant strength decrease when exposed to water circulation, whereas soils compacted wet of optimum exhibit, on the contrary, the lowest permeability and the smallest strength decrease with water circulation. These results suggest that the durability of lime-treated soils could depend not only on the amount of lime added or the curing time but also on the soil permeability and thus on the soil initial state as they are both closely correlated (Le Runigo et al. 2009).

In this context, the present paper aims at assessing i) the impact of different hydraulic conditions, i.e. water contact or water circulation, on the mechanical performance of a limetreated silty soil, and ii) the impact of the soil initial states (lime content, and compaction conditions) on the durability of the mechanical performance. The mechanical properties of the specimens compacted under different initial states after short curing periods will also be investigated. These results will serve as a comparison reference. Then, the impact of water contact and long-term water circulation on the mechanical properties will be described.

\section{Materials and experimental procedures}

\subsection{Materials}

The soil used in this study is the Jossigny silt (see also Cui and Delage 1996; Delage et al. 1996, Cui et al. 2003), sampled in the eastern region of Paris, France. It was dried at ambient temperature $\left(20 \pm 1^{\circ} \mathrm{C}\right)$ for three days, then ground, sieved (passing through a 2-mm sieve) and finally homogenized. The main physical properties are given in Table 1. The X-ray diffraction technique was used to determine the natural soil mineralogical composition. The results showed that it is mainly composed of quartz and feldspar, its clay fraction being composed of illite and kaolinite with a significant amount of interstratified illite and smectite minerals.

The lime used is an industrial quicklime provided by Lhoist which contains $90.4 \%$ of free calcium oxide. The lime modification optimum (LMO) of the soil was determined using the ASTM standard D 6276 and was found to be equal to $1 \%$ of lime by weight. Two different lime contents were tested in this study; the first one equal to the LMO of the soil: $1 \%$, and the second one slightly higher, $3 \%$.

\subsection{Preparation and characteristics of compacted specimens}

The soil was firstly mixed with distilled water in order to reach the desired moisture content and was thereafter sealed in a plastic bag for $48 \mathrm{~h}$ for moisture content homogenisation. Then the moist soil and the lime were thoroughly mixed and dynamically compacted one hour after mixing (compaction procedure based on the French Standards NF P 94-093). The compaction was performed directly in cylindral moulds of $100 \mathrm{~mm}$ high and $50 \mathrm{~mm}$ in diameter using a miniaturised Proctor compaction device similar to that used by Ferber et al. (2008). The compaction was carried out in 10 layers so as to ensure a satisfactory homogeneity.

Untreated specimens were compacted under normal Proctor energy (NE) and at a moisture content close to the optimum moisture content (OMC): the OMC is $17 \%$ but the compaction was conducted at $16 \%$ moisture content and $1.76 \mathrm{Mg} \cdot \mathrm{m}^{-3}$ dry density. In the case 
of lime-treated specimens, three different initial states were considered. The first one corresponds to the state generally looked for at construction sites, namely compaction at the optimum: compaction at OMC under normal Proctor energy (OMC $=21 \%$ for soil treated at $1 \%$ of lime, $\mathrm{OMC}=23 \%$ for soil treated at $3 \%$ of lime); the second one corresponds to a low compaction ( $50 \%$ of the normal Proctor energy, LE) and the third one corresponds to a compaction at a moisture content $3 \%$ higher than the OMC (WMC). The latter two states correspond to two critical cases possibly encountered at construction sites.

After compaction, specimens were sealed using both cellophane paper and wax so as to avoid moisture loss. They were then left to cure at ambient laboratory temperature $(20 \pm$ $1{ }^{\circ} \mathrm{C}$ ) for periods varying from 0 to 25 days. Both density and water content were monitored during the curing period, by measuring the volume using a caliper $( \pm 0.001 \mathrm{~mm})$ and by weighing $( \pm 0.001 \mathrm{~g})$. Little variation in density and water content were observed. Figure 1 presents the different compaction characteristics reached by lime-treated specimens after 25day curing.

\subsection{Water contact and long term percolation devices}

The impact of water contact was investigated by immersing soil specimens after 25-day curing in a solution of distilled water, the weight ratio of liquid to solid being 1 . In order to examine the evolution of the soil mechanical properties with immersion time, four immersion durations were considered: 7, 25, 50 and 110 days.

The effects of long-term water circulation were investigated using a special percolation device. Twelve cells were designed; each cell consists of two perforated aluminium plates of $100 \mathrm{~mm}$ diameter and a plexiglas cylinder of $52 \mathrm{~mm}$ inner diameter and $120 \mathrm{~mm}$ high. Specimens were installed in the cells and wrapped in latex membranes. A cell pressure of $120 \mathrm{kPa}$ was applied and the percolation was performed under a constant hydraulic head of $8 \mathrm{~m}(80 \mathrm{kPa})$. The percolation was conducted per ascensum so as to facilitate air evacuation. The leaching time varied from 110 to 320 days at a constant temperature of $20^{\circ} \mathrm{C}$. Distilled water was chosen as the leaching fluid. The leachates were collected into plastic bottles as water passed through the specimens. Permeability of the specimens was determined based on Darcy's law from the quantity of water collected for a given time of percolation.

\subsection{Mechanical tests}

Unconfined compression tests were carried out on compacted specimens at the end of curing (before immersion) and after different times of immersion and leaching. The tests were carried out at a constant displacement rate of $1 \mathrm{~mm} \cdot \mathrm{min}^{-1}$. Note that all samples tesed were unsaturated; thus a suction effect can be expected. For triaxial tests, by contrast, all samples were initially saturated by water percolation and back pressure application. The tests were performed under undrained condition with pore pressure measurements on untreated specimens and lime-treated specimens after curing and after leaching. Three cell pressures were applied: 350,500 and $800 \mathrm{kPa}$. The back-pressure of $210 \mathrm{kPa}$ was applied; this led to three effective confining pressures: 140, 290 and $590 \mathrm{kPa}$. Shearing was performed at a constant rate of $0.03 \mathrm{~mm} . \mathrm{min}^{-1}$.

\subsection{Physico-chemical tests}

Carbonate content and available lime content were determined at different time of curing and leaching. Carbonate content was determined using the "Dietrich-Frühling" calcimeter by measuring the volume of $\mathrm{CO}_{2}$ developed by acid reacting with the soil. The method used to determine the available lime content of the soil (i.e. lime either in the form of portlandite, $\mathrm{Ca}(\mathrm{OH})_{2}$, or calcium oxide, $\left.\mathrm{CaO}\right)$ is based on the Leduc method: the lime was solubilized by reaction with sugar to form calcium sucrate which is then titrated using a standard acid and a 
solution of $1 / 3$ bromocresol green and $2 / 3$ phenolphthalein as indicator. The acid solution used in this study was a $0.1 \mathrm{M}$ hydrochloric acid solution.

Porewater calcium concentration after 25-day curing was estimated by measuring the calcium concentration of the solution after 24-hour immersion of soil samples cured for 25 days and treated at $1 \%$ or $3 \%$ of lime (weight ratio of liquid to solid equal to 10 ). Leachates calcium concentrations were measured using inductively coupled plasma atomic emission spectrometry (ICP-AES) at different times of percolation. Specimen porewater calcium concentrations were also estimated at different time of leaching, on the basis that the leachate calcium concentration recorded at a given time of percolation is equivalent to the porewater calcium concentration of the soil specimen. It was observed that the porewater calcium concentrations during leaching represent less than $0.006 \%$ of the calcium initially present, and thus can be considered as negligible.

\section{Results}

\subsection{Before immersion}

\subsubsection{Physico-chemical aspect}

Tables 2 and 3 provide the speciation of calcium in the lime-treated specimens compacted at their optimum level (i.e. optimum moisture content under normal Proctor energy, shortened as OMC-NE) during curing. The addition of lime induces a significant increase in the calcium carbonate content for both lime contents: from $0.51 \%$ to $0.77 \%$ in the case of $1 \%$ of lime and to $1.13 \%$ in the case of $3 \%$ of lime after 25 -day curing. The results also show that $77 \%$ of the lime added was consumed after 25-day curing in the case of $1 \%$ of lime, whereas only $54 \%$ of the added lime was consumed in the case of $3 \%$ of lime (these percentages were calculated using the available lime content measured at 0 and 25 days-curing).

It can be also noted that the total calcium content corresponding to the sum of the porewater calcium, carbonates and available lime calcium contents after 25-day curing is significantly below the calcium content initially present in the soil specimens: a difference of $0.19 \%$ and $0.28 \%$ for specimens treated respectively at $1 \%$ and $3 \%$ of lime. It is likely that this difference corresponds to the uptake of calcium for the formation of cementitious compounds. As a result, it can be estimated that the quantity of cementitious compounds formed after 25 -day curing is more significant with a treatment at $3 \%$ of lime (i.e. $+30 \%$ ) than a treatment at $1 \%$ of lime.

\subsubsection{Mechanical properties}

Figure 2 presents the effects of curing and lime content on the unconfined compressive strength (UCS) of specimens compacted at their optimum level (the results presented corresponds for each curing time to an average calculated over three specimens). Curing leads to an increase in UCS for both lime contents. However, the increase is more significant for specimens treated with $3 \%$ of lime. Indeed, the UCS of specimens treated at $1 \%$ of lime increases by only $19 \%$ after 25 -day curing, whereas that of specimens treated at $3 \%$ of lime increases by $42 \%$.

Undrained triaxial tests with pore pressure measurement were performed on specimens treated at $1 \%$ of lime after 90 -day curing and on specimens treated at $3 \%$ of lime after 50-day curing. Figure 3 presents the effective stress paths for three types of specimens (untreated, $1 \%$ and $3 \%$ of lime) under three different confining pressures. A clear increase of shear strength brought by lime can be also observed when comparing the failure envelope of treated soil with that of untreated soil, in agreement with the observation from the unconfined compression tests. However, the difference in shear strength between $1 \%$ and $3 \%$ of lime is quite small. This might be due the shorter curing time for $3 \%$ lime. 
Figure 4 presents the effects of compaction conditions on the UCS of lime-treated specimens. A strong impact is evidenced: compaction at the optimum leads to the highest UCS for both lime contents, about $19 \%$ to $64 \%$ higher than in the case of compaction on the wet side or undercompaction. In addition, despite the higher dry density of lime-treated specimens compacted on the wet side as compared to that of undercompacted specimens (see Figure 1), their UCS was lower than that of undercompacted specimens. This observation suggests that the influence of moisture content or suction is more domininant than that of dry density.

\subsection{After immersion}

\subsubsection{Physico-chemical aspect}

Table 4 presents the evolution of the calcium concentrations recorded at different immersion times: 7, 25, 50 and 110 days. It can be noted that after 7 days, i.e., time needed for the saturation of soil specimens, the calcium concentrations of the specimens treated at both $1 \%$ and $3 \%$ of lime stabilized. This suggests that equilibrium is reached between the solution and lime-treated specimens. The calcium concentrations recorded for specimens treated at $3 \%$ of lime (mean value of $600 \mathrm{mg} \cdot \mathrm{L}^{-1}$ ) are much higher than those of specimens treated at $1 \%$ of lime (mean value of $115 \mathrm{mg} . \mathrm{L}^{-1}$ ).

\subsubsection{Mechanical properties}

The evolution with immersion time of UCS of lime-treated specimens compacted at their optimum level is presented in Figure 5, together with the values before immersion. Note that it was not possible to determine the effect of immersion on the UCS of untreated specimens as they almost immediately began to disintegrate when immersed in water. Their UCS was therefore considered as zero once immersed. In the case of lime-treated specimens, an immersion of 7 days (i.e. saturation of specimens) leads to a significant UCS decrease. However, their UCS remained much higher than that evaluated for the untreated specimens (i.e. zero). The results also showed that an immersion time longer than 7 days does not result in further UCS decrease: for both lime contents, the UCS remained close to that measured after 7-day immersion. A relatively larger decrease was observed for the $3 \%$ lime-treated specimens than for the $1 \%$ lime-treated specimens $(37 \%$ and $47 \%$ for specimens treated respectively with $1 \%$ and $3 \%$ of lime). As a consequence, the large difference in UCS recorded after 25-day curing between $1 \%$ of lime and $3 \%$ of lime (Figure 2) was reduced after immersion: the specimens treated at $1 \%$ and $3 \%$ of lime presented similar UCS, with a mean value of $290 \mathrm{kPa}$ for $1 \%$ of lime after saturation and a mean value of $310 \mathrm{kPa}$ for $3 \%$ of lime after saturation.

\subsection{During and after leaching}

\subsubsection{Physico-chemical aspects}

Table 2 provides the speciation of calcium during curing and leaching for the specimens treated at $1 \%$ of lime and compacted at different initial conditions. Two distinct evolutions can be observed for the specimens compacted at the optimum level during leaching. These are quoted as $\mathrm{C} 1$ and $\mathrm{C} 2$ : the quantity of calcium leached at a given time of percolation appears to be larger for the specimens 1\%-OMC-NE-C1 than for the specimens 1\%-OMC-NE-C2: $0.12 \%$ of calcium was leached for the specimens $1 \%$-OMC-NE-C 1 after 90 days against $0.09 \%$ for the specimens $1 \%$-OMC-NE-C2 after 200 days. The available calcium content of the specimens $1 \%$-OMC-NE-C1 appears lower than that of the specimens $1 \%$-OMC-NE-C2 at a given time of percolation (only $0.04 \%$ of $\mathrm{Ca}$ for the specimens $1 \%$-OMC-NE-C1 after 90-day leaching and still $0.09 \%$ after 200-day leaching for the specimens 1\%-OMC-NE-C2). However, despite these differences, the carbonates and the total calcium content of the 
specimens 1\%-OMC-NE-C1 and 1\%-OMC-NE-C2 are similar whatever the leaching time. If considering that the difference between the calcium content initially present in the soil and the total calcium content at a given time is representative of the amount of cementitious compounds, it can be deduced that the quantity of cementitious compounds remain unchanged during leaching.

The behaviour of specimens compacted wet of optimum is similar to that of specimens $1 \%$-OMC-NE-C2. The behaviour of undercompacted specimens (1\%-OMC-LE) can be compared to that of specimens 1\%-OMC-NE-C1: in both cases, a large quantity of calcium was leached rapidly. However, unlike for the specimens $1 \%$-OMC-NE-C1, the total calcium content of the undercompacted specimens is higher than that of specimens compacted at their optimum level after the same leaching time, thus indicating a lower quantity of cementitious compounds in the undercompacted specimens.

Table 3 gives the speciation of calcium during curing and leaching for the specimens treated at $3 \%$ of lime and compacted at different initial conditions. Available lime or calcium carbonate contents of the specimens compacted at the optimum decreases with percolation time: $86 \%$ decrease for available lime and $22 \%$ decrease for carbonates are recorded after 320-days leaching compared to the values measured after curing. In addition, as for the specimens $1 \%$-OMC-NE-C2, the percentage of leached calcium increases. However, unlike for the specimens treated at $1 \%$ of lime, the total calcium content decreases upon leaching. Based on the assumption that the difference between the initial calcium content and the total calcium content at a given time represents the amount of cementitious compounds, it can be deduced that cementitious compounds were formed during leaching. The results further show that undercompaction leads to a rapid leaching of large calcium quantity: the percentage of leached calcium after 150-day percolation is comparable with that after 320-day percolation for the specimens compacted at the optimum level; the total calcium content of the undercompacted specimens after 150-day leaching is similar to that of specimens compacted at optimum after curing. Moreover, the percentage of leached calcium after 150-day percolation for a compaction on the wet side appears to be significantly lower than that for the specimens compacted at their optimum. Finally, it can be noted after 150-day leaching that the total and available lime calcium contents of the specimens compacted wet of optimum are higher than that of the specimens compacted at the optimum. This suggests that a larger quantity of cementitious compounds could be formed in the specimens compacted wet of optimum.

\subsubsection{Geotechnical properties}

Table 5 gives the initial permeability (measured immediately after saturation) of the different specimens considered in this study. The permeability of the specimens treated at $1 \%$ of lime and compacted at the optimum level varies according to the type of the specimen considered. Indeed, the initial permeability of the specimens 1\%-OMC-NE-C1 and 1\%-OMC-NE-C2 differ by about one order of magnitude, the initial permeability of the specimens $1 \%$-OMCNE-C1 being higher. The results further show that the initial permeability of the specimens treated at $3 \%$ of lime and compacted at the optimum is close to that of the specimens $1 \%$ OMC-NE-C2 $\left(\mathrm{k}_{\mathrm{i}} \sim 7.1 \times 10^{-10} \mathrm{~m} . \mathrm{s}^{-1}\right.$ for specimens $1 \%$-OMC-NE-C2 and $\mathrm{k}_{\mathrm{i}} \sim 1.4 \times 10^{-10} \mathrm{~m} . \mathrm{s}^{-1}$ for specimens treated at $3 \%$ of lime and compacted at their optimum level). Furthermore, the values of initial permeability of undercompacted lime-treated specimens are quite close for both lime contents; they are significantly larger than that of the specimens compacted at the optimum level, except for the specimens 1\%-OMC-NE-C1 with an initial permeability close to that of undercompacted specimens. Finally, the initial permeability of lime-treated specimens compacted on the wet side are similar; it is slightly lower than that of the specimens compacted at the optimum level (except for specimens 1\%-OMC-NE-C1). 
Figure 6 presents the leaching effect on the UCS of untreated and lime-treated specimens compacted at their optimum level. Surprisingly, leached untreated specimens showed higher UCS than that showed by immersed untreated specimens (Figure 6a). Secondary consolidation of the soil specimens caused by the confining pressure applied could be at the origin of this result. In the case of specimens treated at $1 \%$ of lime, large scatter is observed (Figure 6b). Specimens 1\%-OMC-NE-C1 showed a large UCS decrease after only 90-day leaching (i.e. decrease of $69 \%$ ); the UCS after 90-day leaching is similar to that of untreated specimens after leaching. The decrease recorded after 320-day leaching for these specimens is of the same order (i.e. decrease of $77 \%$ ). By contrast, the UCS of the specimens 1\%-OMC-NE-C2 remained close to that after saturation (i.e. $290 \mathrm{kPa}$ ) even after 200-day percolation, and much higher than that of untreated specimens. In the case of specimens treated at $3 \%$ of lime, a small UCS increase was recorded after 120-day and 200-day leaching (Figure 6c). However, a significant decrease (i.e. 32\%) was noted after 320-day leaching. Nevertheless, the UCS presented by these specimens after 320-day leaching remained significantly higher than that observed on the untreated specimens after 150-day leaching. Finally, the UCS after leaching observed on specimens 1\%-OMC-NE-C1 is much lower than that observed on specimens treated at $3 \%$ of lime; the UCS of specimens 1\%-OMC-NE-C2 after 200-day leaching is comparable with that of specimens treated at $3 \%$ of lime.

Figure 7 presents a comparison of triaxial shear strength between untreated specimens, specimens treated at $1 \%$ of lime after 25-day curing and specimens treated at $1 \%$ of lime after 25-day curing followed by 150-day leaching. It appears that leaching leads to a decrease in shear strength; the value of shear strength of the soil after leaching is similar to that of the untreated soil. Figure 8 presents a comparison of triaxial shear strength between untreated specimens, specimens treated at $3 \%$ of lime after 25 -day curing and specimens treated at $1 \%$ of lime after 25-day curing followed by 200-day leaching. Unlike the soil treated at $1 \%$ of lime, the soil treated at $3 \%$ lime shows a negligible decrease in shear strength with leaching. Indeed, the treated specimens after curing and after leaching show similar shear strength.

Comaprison between the results from triaxial tests and UCS tests shows that consistent leaching effect was identified by the two types of tests: a significant decrease of shear strength due to leaching for $1 \%$ lime addition and a negligeable decrease for $3 \%$ lime addition. Nevertheless, when comparing the values from UCS tests and that from triaxial tests, it seems that the shear strength identified by the triaxial tests (deviator stress values at zero net mean effective stress) is much lower than that by the UCS tests. This is possibly due to the effect of stess paths. Another possibility is that the samples in the triaxial tests were probably better saturated (by water percolation and back pressure application) than the samples in the UCS tests (by immersion or leaching).

\section{Discussion}

From a hydraulic point of view, the life of a lime-treated soil in an embankment or an hydraulic earth structure (i.e. dikes, dams, canals) can be characterised by three stages: curing, immersion and in some cases water circulation.

The first stage corresponds to the time period after lime treatment and compaction, and in the present study to the curing period. During this stage, the external hydraulic conditions in field are supposed to remain approximately constant without heavy flooding, intense rainfall or drying. The addition of lime induces a significant improvement of the soil strength (Figure 2). This improvement is also noted for specimens compacted on the wet side or with a low energy; but such initial states appear unfavourable as they lead to lower strengths (Figure 4). The origin of these mechanical improvements is commonly attributed to the different physicochemical modifications of the soil, including the $\mathrm{pH}$ increase and cementitious compound precipitation (Brandl 1981; Balasubramaniam and Buensuceso 1989; Bell 1996; Little 1995). 
As a higher immediate UCS was observed for 3\% lime in Figure 2, it can be concluded that increasing lime content enhances different phyciso-chemical reactions mentioned above. Moreover, Figure 2 also shows that the UCS increase is more significant in the case of $3 \%$ lime (42\% increase for $3 \%$ lime against $19 \%$ increase for $1 \%$ lime after 25 -day curing). This evidences that more physico-chemical reactions occurs in an environment with higher lime content. This time-dependent reactions are mainly cementitious compound precipitation and crystallisation as mentioned by several authors (Eades and Grim 1960, Omrsby and Kinter 1973; Little 1995). Examination of the UCS variations in Figure 4 shows that the increase rate of the wet sample WMC-NE is similar to that of the sample at optimum (OMC-NE) for both $1 \%$ and $3 \%$ lime content; the increase rate of the samples compacted under lower energy (thus lower density, see Figure 1) is significant larger. This evidences that the cementitious compound precipitation is probably more significant in case of low density with large poresspace.

The results of physico-chemical characterisation support the explanation made on the better mechanical performance recorded for specimens treated at a higher lime content (see Figures 2 and 3). Indeed, Tables 2 and 3 indicate that larger quantity of cementitious compounds was formed in case of 3\% lime. The physico-chemical analyses also show that a large part of the added lime is still available after curing (Tables 2 and 3), especially in the case of $3 \%$ of lime, indicating that only a small part of lime participates in the cementation of the soil; this seems to show that the formation of cenmentitious compounds is dependent rather on the chemical properties of the environment $(\mathrm{pH}$ value for instance) than on the available quantity of lime in the soil.

The results from triaxial tests suggest that a treatment at $3 \%$ of lime after 50 -day curing shows similar mechanical performance to the treatment at $1 \%$ of lime after 90 -days curing (see Figure 3), showing that a comparable amount of cementitious compounds was formed in the two cases. In other words, with $3 \%$ of lime less time is needed than $1 \%$ of lime to obtain the same amount of cementitious compounds. This observation shows that greater kinetics can be obtained for cementitious compounds precipitation when increasing lime content to a value larger than the LMO (1\% for the studied Jossigny silt). Eades and Grim 1966) and Little (1995) also observed that the addition of a lime quantity corresponding to the LMO of the soil does not seem to be sufficient to create good conditions for the formation of pozzolanic compounds. Obviously, using LMO only to describe the conditions for pozzolanic compounds formation is not enough; the results obtained in this study shows clearly that it is important to consider the lime content-dependent kinetics for the cementitious compounds precipitation precipitation.

In the second stage, the soil is wetted and possibly saturated; this can be the case for the base of an embankment submitted to flooding or for hydraulic earth structures. The results clearly show that the mechanical strength decreases significantly, whatever the lime content added (Figure 5). The decrease of mechanical strength due to suction decrease is common results for unsaturated soils (see for instance Cui and Delage 1996). Despite these decreases, it has been found that the soil behaviour is fully modified by the addition of lime since the UCS recorded after immersion is much higher than that observed on non-immersed untreated specimens. Moreover, when considering the UCS after saturation, it appears that the final mechanical strength does not seem to be dependent on the initial lime content (approximately $300 \mathrm{kPa}$ for both lime contents considered).

In the last stage, water circulates through the soil; this can be the case of hydraulic earth structures such as dikes, dams and canals. The UCS results clearly show that the worst consequence of water circulation is obtained with specimens presenting the highest permeability, i.e., the undercompacted specimens and one of the specimens treated with $1 \%$ 
of lime (series C1). Furthermore, the lowest permeability, e.g. for specimens compacted wet of optimum, leads to the smallest strength decrease (Figure 6). The relative stability of the shear strength parameters determined from triaxial tests on specimens treated at $3 \%$ of lime after leaching supports these observations (Figure 8). However, the specimens treated at $1 \%$ of lime and quoted as C2 present, after 25-day curing followed by 150-day leaching, quite small values of shear strength (Figure 7), as if leaching erased all improvement by lime addition. More tests are needed to clarify this point. In spite of this, it can be concluded that the larger the quantity of water circulating within the soil specimen, the faster and the larger the strength decrease. This indicates that the prevailing parameter in terms of durability is not the percolation time but rather the volume of water which passes through the soil. The clear UCS decrease observed on specimens treated at $3 \%$ of lime after 320 days (Figure 6) suggests that a critical water volume was reached for these specimens, despite their low permeability (Table 5).

\section{Conclusion}

This paper assessed the impact of different hydraulic conditions as water immersion and water circulation on the mechanical performance of a lime-treated silty soil. The effect of the soil initial states (lime content and compaction conditions) was also investigated. Emphasis was put on the effect of curing time.

The results indicated that curing time leads to the formation of increasing amounts of cementitious compounds and hence strengthening the soil. It was also evidenced that the higher the lime content, the better the mechanical performance.

A lime content (3\%) larger than the LMO (1\% in the case of Jossigny silt) gives rise to a greater kinetics for cementitious compounds precipitation, showing the importance to consider the lime content-dependent kinetics when defining the conditions for cementitious compounds precipitation.

Water contact led to a significant decrease in the shear strength, mainly during the saturation phase. Once the soil was saturated, the impact of lime content was found to be less significant than during curing.

The mechanical performance of the soil exposed to water circulation is related to the quantity of water passing through the soil and hence to its permeability rather to the duration of water circulation. As a result, low permeability limits the strength decrease due to water circulation. In practice, such permeability can be obtained by compacting the soil under either a high energy or at high moisture contents.

\section{Acknowledgments}

The authors would like to thank the Laboratoire Environnement, Géomécanique et Ouvrages (LAEGO) for carrying out the triaxial tests.

\section{References}

Balasubramaniam, A.S., and Buensuceso, B.R. 1989. On the overconsolidated behaviour of lime-treated soft clay. $11^{\text {th }}$ international conference on soil mechanics and foundation engineering, Rio de Janeiro, Brasil. 35-30.

Balasubramaniam, A.S., Buensuceso, B.R., Oh, E.Y., Bolton, M., Bergado, D.T., and Lorenzo, G.A. 2005. Strength degradation and critical state seeking behaviour of lime treated soft clay. In Best Practice and recent advances 1, International conference on deep mixing, Deep mixing '05, Stockholm, (Sweden). 35-40.

Bell, F.G. 1996. Lime stabilization of clay minerals and soil. Engineering geology 42, 223237. 
Brandl, H. 1981. Alteration of soil parameters by stabilization with lime. $10^{\text {th }}$ international conference on soil mechanics and foundation engineering, Stockholm. 587-594.

Cui Y. J. \& Delage P. 1996. Yielding and plastic behaviour of an unsaturated compacted silt. Géotechnique 46 (2), 291-311.

Cui Y.J., Delage P., Alzoghbi P. 2003. Retention and transport of a hydrocarbon in a silt. Géotechnique 53(1), 83-91.

Delage P., Audiguier M., Cui Y. J. \& Howat M. 1996. Microstructure of a compacted silty clay. Canadian Geotechnical Journal 33, 150-158.

De Bel, R., Bollens, Q., Duvigneaud, P.H., and Verbrugge, J.C. 2005. Influence of curing time, percolation and temperature on the compressive strength of a loam treated with lime. International symposium TREMTI, paper $\mathrm{n}^{\circ} \mathrm{C} 022: 10 \mathrm{p}$.

Eades, J.L., and Grim, R.E. 1960. Eades J.L., Grim R.E. (1960). Reaction of hydrated lime with pure clay minerals in soil stabilization. Highway Research Board Bulletin, $\mathrm{n}^{\circ}$ 262, 51-63.

Eades, J.L., and Grim, R.E. 1966. A quick test to determine lime requirements for lime stabilization. Highway Research Board Bulletin, n¹39, 61-72.

Estéoule J., Perret P. (1979). Étude expérimentale des phénomènes de stabilisation des sols fins par la chaux. Bulletin de liaison des Laboratoires des Ponts et Chaussées, $\mathrm{n}^{\circ} 99$, 99-109.

Ferber V., Auriol J.C., Cui Y.J., Magnan J.P. 2008. On the wetting-induced volume changes of compacted clays and low plasticity soils. Canadian Geotechnical Journal 45(3), 252-265.

Fossberg, P.E. 1965. Some fundamentals engineering properties of a lime stabilized clay. $6^{\text {th }}$ international conference on soil mechanics and foundation engineering, Montréal. 21225 .

Le Runigo B., Cuisinier O., Cui Y.J., Ferber V., Deneele D. 2009. Impact of the initial state on fabric and permeability of a lime treated silt under long term leaching. Canadian Geotechnical Journal 46 (11), 1243-1257.

Little, D.N. 1995. Stabilization of pavement subgrades and base courses with lime. Edition National Lime Association, 219 p.

McCallister, L.D. 1990. The effects of leaching on lime-treated expensive clays. PhD thesis, University of Texas at Arlington, 417p.

McCallister, L.D. and Petry, T.M. 1992. Leach tests on lime-treated clays. Geotechnical testing journal, 15(2), 106-114.

Petry, T.M. and Berger, E.A. 2006. Impact of moisture content on strength gain in limetreated soils. Transportation research board, $85^{\text {th }}$ annual meeting, article $n^{\circ} 06-2764$, $16 \mathrm{p}$.

Rogers, C.D.F., and Glendinning, S. 1996. Modification of clays soils using lime. In Lime stabilization. Thomas Telford, London. 99-112.

Wissa, A.E.Z., Ladd, C.C. and Lambe, T.W. 1965. Effective stress strength parameters of stabilized soils. International conference on soil mechanics and foundation engineering, Montréal. 412-416. 


\section{List of Tables}

Table 1. Main geotechnical and physico-chemical properties of the soil

Table 2. Speciation of calcium after 0 and 25-day curing and after different leaching time for specimens treated at $1 \%$ lime and compacted at different initial states

Table 3. Speciation of calcium after 0 and 25-day curing and after different leaching time for specimens treated at $3 \%$ lime and compacted at different initial states

Table 4. Evolution of the calcium concentrations of the solution in which lime-treated specimens compacted at their optimum Proctor are immersed

Table 5. Initial permeability of untreated and lime-treated soils subjected to leaching

\section{List of Figures}

Figure 1. Characteristics of lime-treated specimens compacted under different initial conditions and after 25 day curing: $1 \%$ of lime (a), $3 \%$ of lime (b)

Figure 2. Effect of curing and of lime content on the unconfined compression strength of specimens compacted at their optimum moisture content under normal Proctor energy

Figure 3. Effect of lime treatement on the triaxial shear strength after 90 -day curing for $1 \%$ of lime and after 50 day-curing for $3 \%$ of lime

Figure 4. Effect of initial compaction conditions on the unconfined compression strength of specimens treated both at $1 \%$ (a) and $3 \%$ (b) of lime

Figure 5. Effect of immersion on the unconfined compression strength of lime-treated specimens compacted at their optimum: $1 \%$ of lime (a), $3 \%$ of lime (b)

Figure 6. Effect of leaching on the unconfined compression strength of lime-treated specimens compacted at their optimum: $0 \%$ of lime (a), $1 \%$ of lime (b), $3 \%$ of lime (c)

Figure 7. Effect of water circulation on the shear strength of the soil treated at $1 \%$ of lime (specimens compacted at their respective Proctor level, water circulation of 150 days)

Figure 8. Effect of water circulation on the shear strength of the soil treated at $3 \%$ of lime (specimens compacted at their respective optimum Proctor level, water circulation of 200 days) 
Table 1. Main geotechnical and physico-chemical properties of the soil

\begin{tabular}{lc}
\hline Geotechnical properties & \\
\hline Liquid limit, $\mathrm{w}_{\mathrm{L}}(\%)$ & 37.0 \\
Plastic limit, $\mathrm{w}_{\mathrm{P}}(\%)$ & 18.7 \\
Plasicity index, $\mathrm{I}_{\mathrm{P}}(\%)$ & 18.3 \\
Soil grain density, $\rho_{\mathrm{s}}\left(\mathrm{Mg} \cdot \mathrm{m}^{-3}\right)$ & 2.69 \\
Clay fraction $(<2 \mu \mathrm{m}, \%)$ & 29.4 \\
\hline Physico-chemical properties & 8.0 \\
\hline Soil $\mathrm{pH}$ & 15.1 \\
Cation exchange capacity (meq/100g) & 1.30 \\
Carbonate content $(\%)$ & 1.0 \\
Lime modification optimum, LMO $(\%$ of lime) & \\
\hline
\end{tabular}

Table 2. Speciation of calcium after 0 and 25-day curing and after different leaching time for specimens treated at $1 \%$ lime and compacted at different initial states

\begin{tabular}{|c|c|c|c|c|c|c|c|}
\hline Specimens type & $\begin{array}{l}\text { Curing } \\
\text { (days) }\end{array}$ & $\begin{array}{c}\text { Leaching } \\
\text { time } \\
\text { (days) }\end{array}$ & $\begin{array}{c}\text { Carbonates } \\
(\% \mathrm{Ca})\end{array}$ & $\begin{array}{c}\text { Available } \\
\text { lime } \\
(\% \mathrm{Ca})\end{array}$ & $\begin{array}{c}\text { Porewater } \\
\text { calcium }^{\mathrm{a}} \\
(\% \mathrm{Ca})\end{array}$ & $\begin{array}{l}\text { Leached } \\
\text { calcium } \\
(\% \mathrm{Ca})\end{array}$ & $\begin{array}{c}\text { Total } \\
\text { calcium }^{\mathrm{b}} \\
(\% \mathrm{Ca})\end{array}$ \\
\hline $1 \%$-OMC-NE & 0 & - & 0.51 & 0.64 & - & - & 1.15 \\
\hline $1 \%$-OMC-NE & 25 & - & 0.77 & 0.15 & 0.03 & - & 0.95 \\
\hline 1\%-OMC-NE-C1 & 25 & 90 & - & 0.04 & - & 0.12 & - \\
\hline $1 \%$-OMC-NE-C 1 & 25 & 320 & 0.78 & 0.04 & - & 0.14 & 0.96 \\
\hline $1 \%$-OMC-NE-C2 & 25 & 150 & 0.77 & 0.10 & - & 0.07 & 0.94 \\
\hline $1 \%$-OMC-NE-C 2 & 25 & 200 & 0.78 & 0.09 & - & 0.09 & 0.96 \\
\hline 1\%-OMC-LE & 25 & 150 & 0.87 & 0.04 & - & 0.17 & 1.08 \\
\hline $1 \%$-WMC-NE & 25 & 150 & 0.77 & 0.11 & - & 0.07 & 0.95 \\
\hline
\end{tabular}

NB: No difference between the sample preparation, compaction and curing conditions of specimens treated at $1 \%$ of lime and quaoted $\mathrm{Cl}$ and $\mathrm{C} 2$. However, these are quoted as $\mathrm{Cl}$ and $\mathrm{C} 2$ and presented separately in the table since large differences in the results were noticed

${ }^{a}<0.006 \%$ of $\mathrm{Ca}$ during leaching, hence negligible

${ }^{\mathrm{b}}$ corresponds to the addition of carbonates, available lime, porewater calcium and leached calcium

Table 3. Speciation of calcium after 0 and 25-day curing and after different leaching time for specimens treated at $3 \%$ lime and compacted at different initial states

\begin{tabular}{lccccccc}
\hline Specimens type & $\begin{array}{c}\text { Curing } \\
\text { (days) }\end{array}$ & $\begin{array}{c}\text { Leaching } \\
\text { time } \\
\text { (days) }\end{array}$ & $\begin{array}{c}\text { Carbonates } \\
(\% \mathrm{Ca})\end{array}$ & $\begin{array}{c}\text { Available } \\
\text { lime } \\
(\% \mathrm{Ca})\end{array}$ & $\begin{array}{c}\text { Porewater } \\
\text { calcium }^{\mathrm{a}} \\
(\% \mathrm{Ca})\end{array}$ & $\begin{array}{c}\text { Leached } \\
\text { calcium } \\
(\% \mathrm{Ca})\end{array}$ & $\begin{array}{c}\text { Total } \\
\text { calcium }^{\mathrm{b}} \\
(\% \mathrm{Ca})\end{array}$ \\
\hline 3\%-OMC-NE & 0 & - & 0.51 & 1.92 & - & - & 2.43 \\
\hline $3 \%$-OMC-NE & 25 & - & 1.13 & 0.88 & 0.14 & - & 2.15 \\
\hline $3 \%$-OMC-NE & 25 & 120 & - & 0.59 & - & 0.31 & - \\
\hline $3 \%$-OMC-NE & 25 & 150 & 1.10 & 0.47 & - & 0.36 & 1.93 \\
\hline $3 \%$-OMC-NE & 25 & 200 & 1.00 & 0.41 & - & 0.47 & 1.88 \\
\hline $3 \%$-OMC-NE & 25 & 320 & 0.88 & 0.12 & - & 0.77 & 1.77 \\
\hline $3 \%$-OMC-LE & 25 & 150 & 1.15 & 0.23 & - & 0.77 & 2.15 \\
\hline $3 \%$-WMC-NE & 25 & 150 & 1.05 & 0.66 & - & 0.16 & 1.87 \\
\hline
\end{tabular}

${ }^{\mathrm{a}}<0.006 \%$ of $\mathrm{Ca}$ during leaching, hence negligible

${ }^{\mathrm{b}}$ corresponds to the addition of carbonates, available lime, porewater calcium and leached calcium 
Table 4. Evolution of the calcium concentrations of the solution in which lime-treated specimens compacted at their optimum Proctor are immersed

\begin{tabular}{cccccc}
\hline & \multicolumn{5}{c}{ Calcium concentrations $\left(\mathrm{mg} . \mathrm{L}^{-1}\right)$} \\
\hline & 0 day & 7 days & 25 days & 50 days & 110 days \\
\hline 1\%-OMC-NE & 0 & 110 & 120 & 99 & 130 \\
\hline $3 \%$-OMC-NE & 0 & 580 & 625 & 590 & 620 \\
\hline
\end{tabular}

Table 5. Initial permeability of untreated and lime-treated soils subjected to leaching

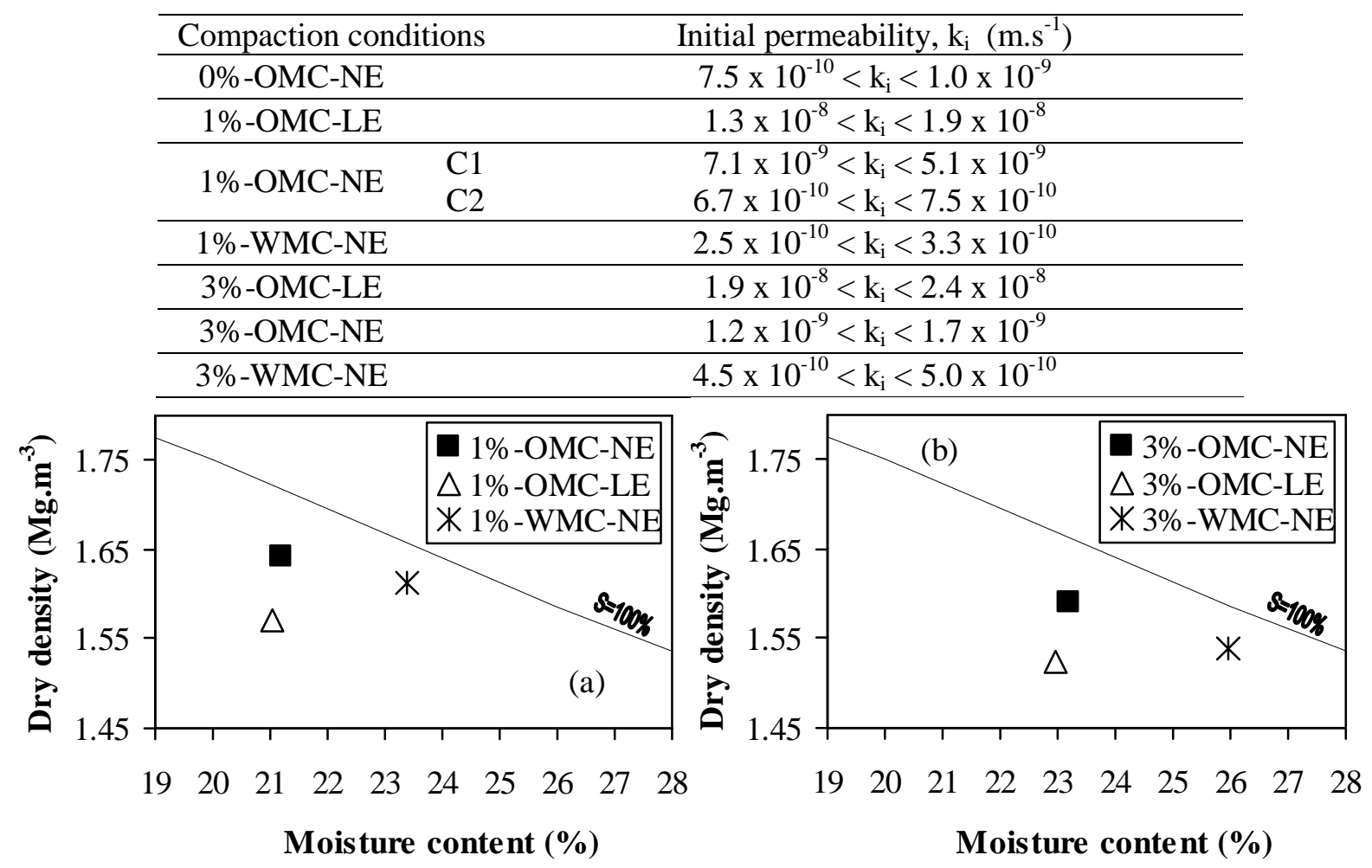

Figure 1. Characteristics of lime-treated specimens compacted under different initial conditions and after 25 day curing: $1 \%$ of lime (a), $3 \%$ of lime (b). 


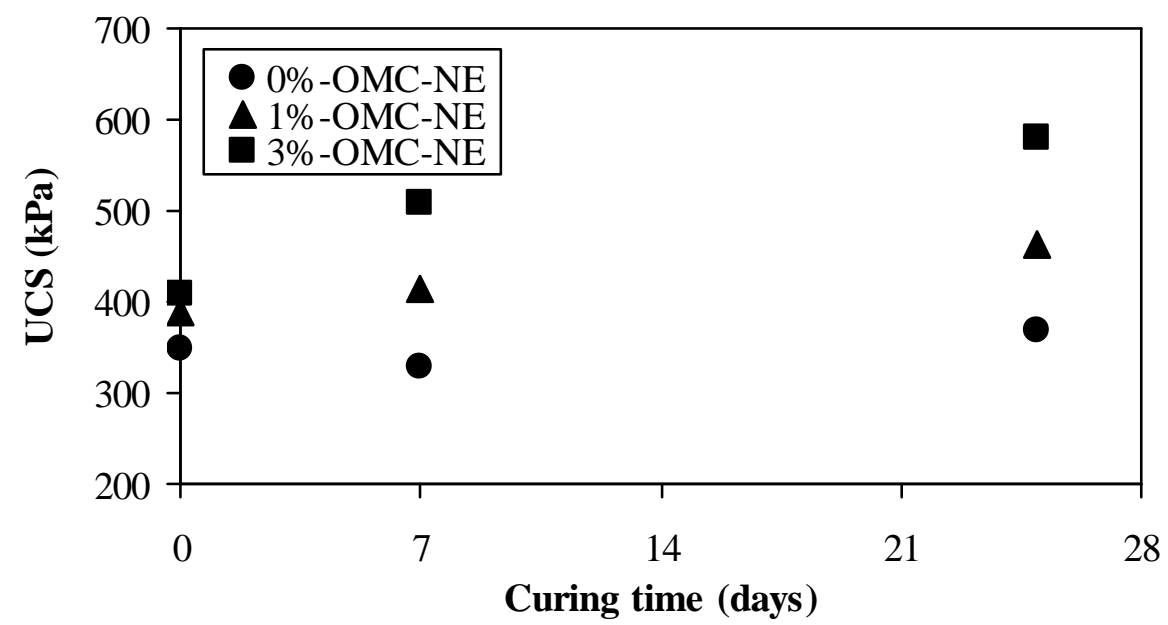

Figure 2. Effect of curing and of lime content on the unconfined compression strength of specimens compacted at their optimum moisture content under normal Proctor energy.

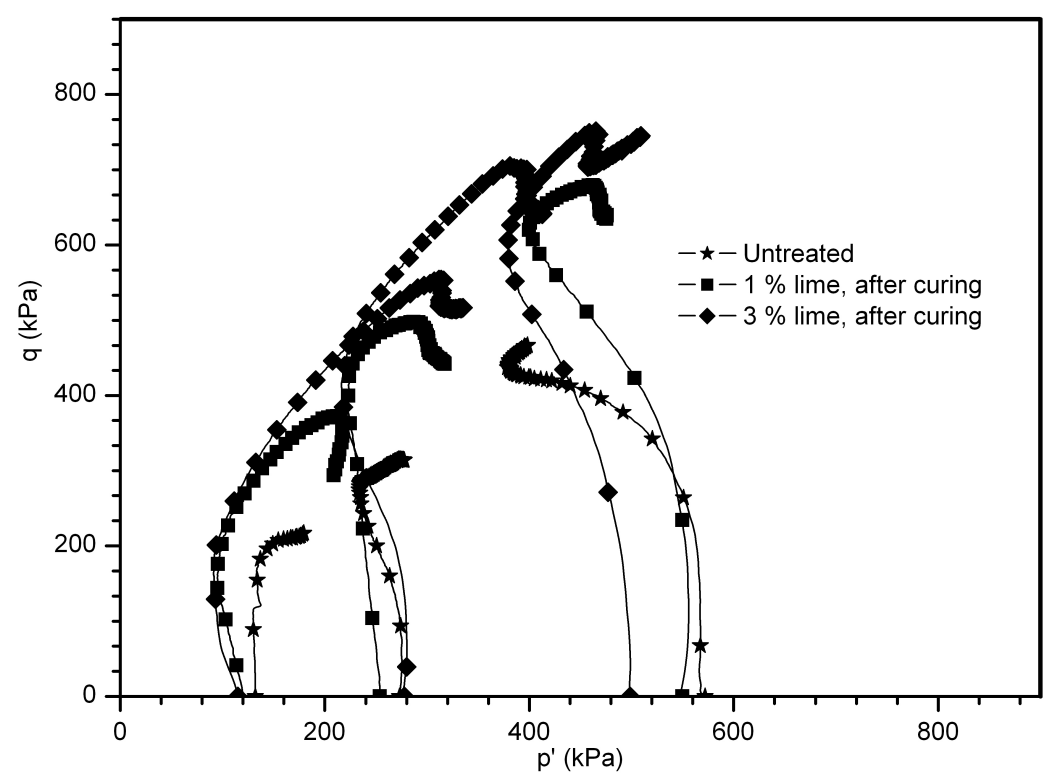

Figure 3. Effect of lime treatement on the triaxial shear strength after 90 -day curing for $1 \%$ of lime and after 50 day-curing for $3 \%$ of lime. 

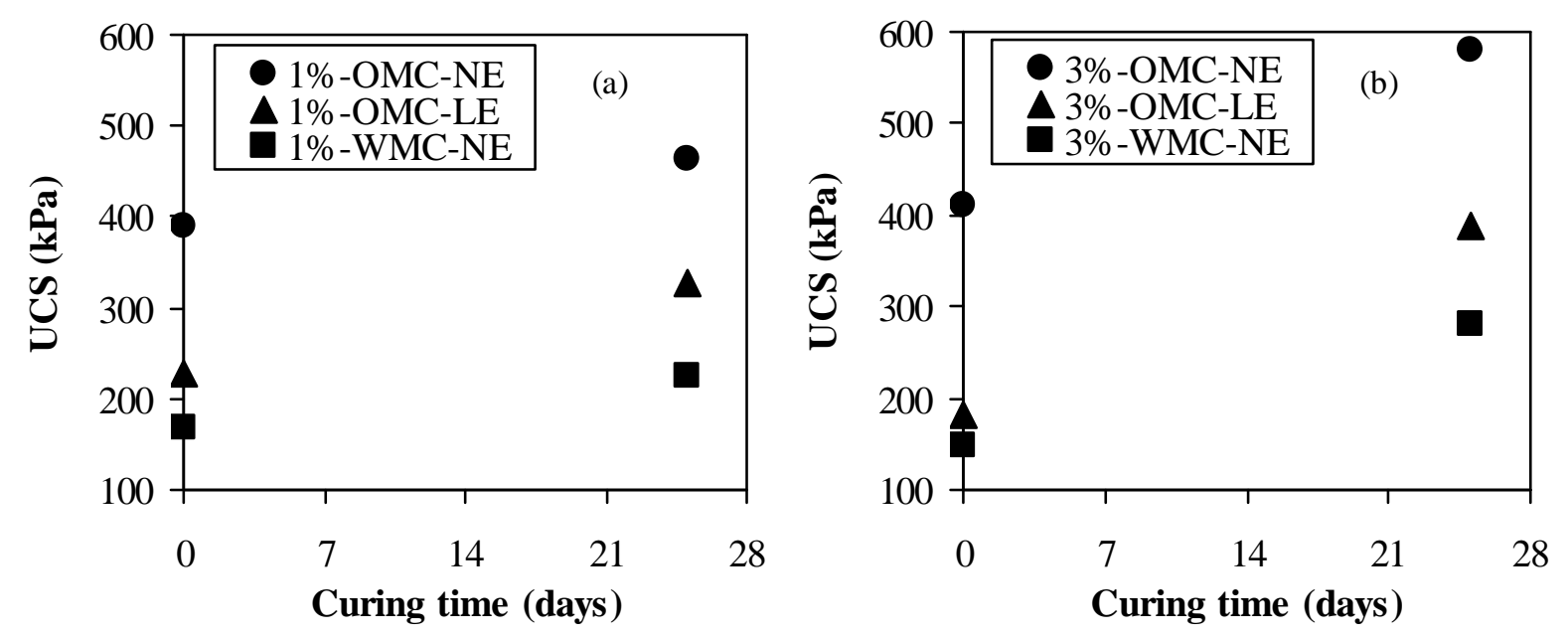

Figure 4. Effect of initial compaction conditions on the unconfined compression strength of specimens treated both at $1 \%$ (a) and $3 \%$ (b) of lime.
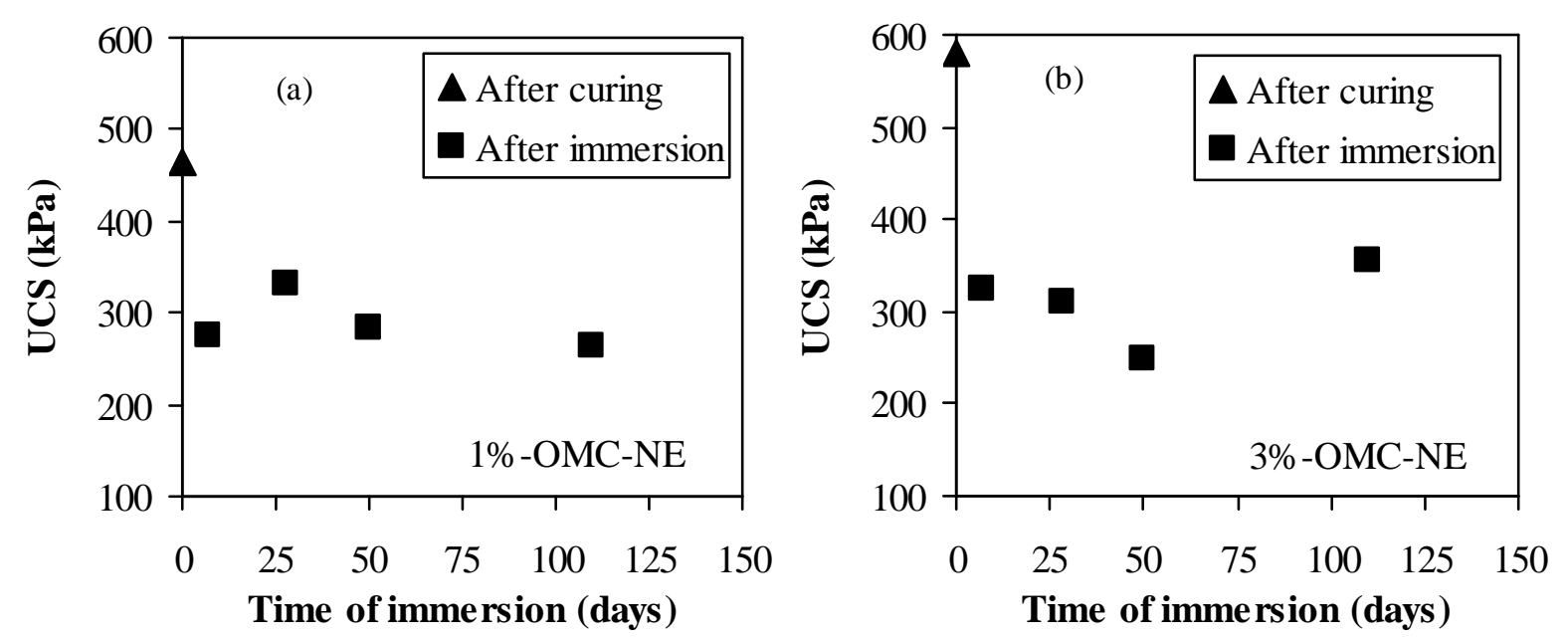

Figure 5. Effect of immersion on the unconfined compression strength of lime-treated specimens compacted at their optimum: $1 \%$ of lime (a), $3 \%$ of lime (b). 


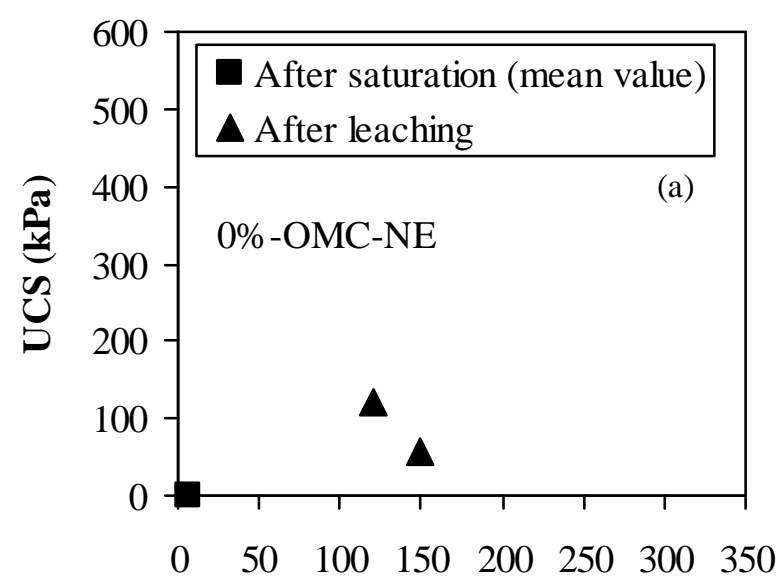

Time of leaching (days)
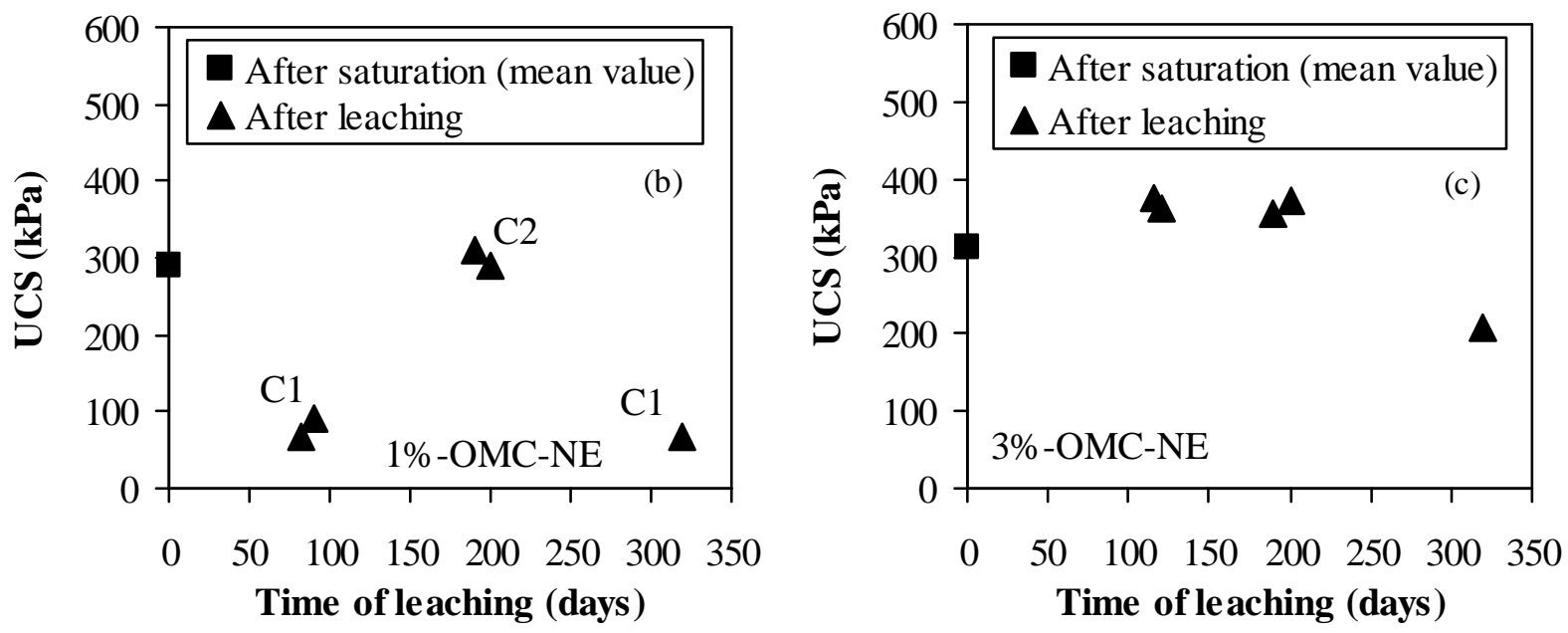

Figure 6. Effect of leaching on the unconfined compression strength of lime-treated specimens compacted at their optimum: $0 \%$ of lime (a), $1 \%$ of lime (b), $3 \%$ of lime (c).

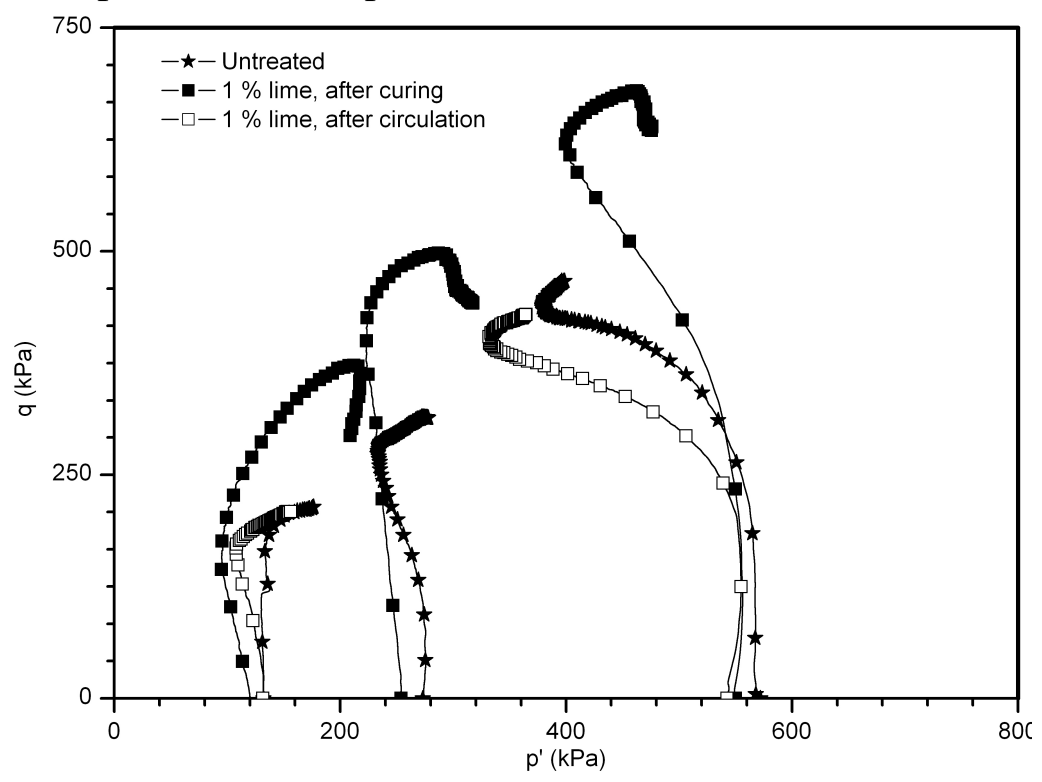

Figure 7. Effect of water circulation on the shear strength of the soil treated at $1 \%$ of lime (specimens compacted at their respective Proctor level, water circulation of 150 days) 


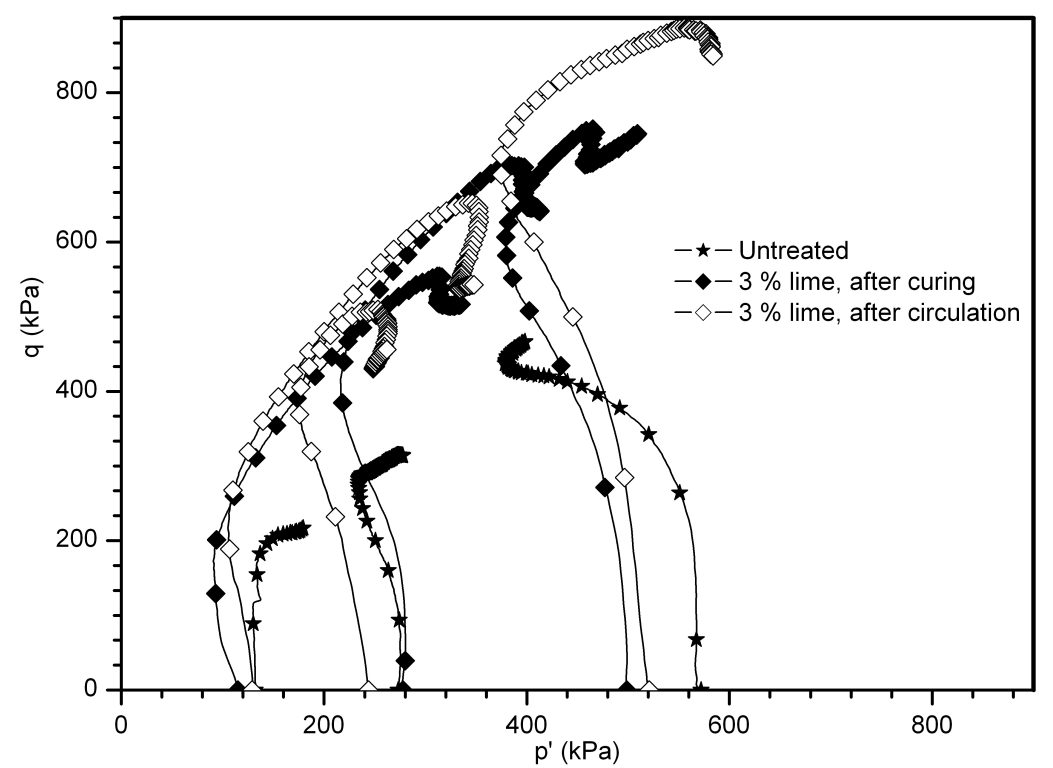

Figure 8. Effect of water circulation on the shear strength of the soil treated at $3 \%$ of lime (specimens compacted at their respective optimum Proctor level, water circulation of 200 days) 